REMLATE DIE MUALES

Campinas-SP, v.40, n.2, pp. 723-750, jul./dez. 2020

\title{
Palhaços mortos, poetas e outros párias
}

\author{
Dead Clowns, Poets and other Outcasts
}

\author{
Francine Ricieri ${ }^{1}$
}

Resumo: O ensaio pretende analisar a publicação, na revista Kosmos (1907), de "Morte do palhaço", de Gonzaga Duque. A escolha dessa publicação em específico (há, pelo menos, duas outras versões, em livros de 1914 e 1996) decorre de aspectos nela presentes considerados decisivos para alguns dos sentidos passíveis de discussão a partir do texto. Facilmente assimilável a uma interpretação metapoética que coloca em questão a arte como experimentação, "Morte do palhaço" parece demonstrar, ainda, certo imbricamento entre o que seria da ordem do prosaico e o que seria da ordem do poético, nesse momento histórico específico, com possibilidade de associação a questões teóricas mais recentemente propostas, que levariam à discussão da possibilidade de trânsito entre dois ideais de escrita (um ideal "alto" e um ideal "baixo"). Uma questão adicional diz respeito à estreita relação observável, na versão da Kosmos, entre o texto propriamente dito e algumas ilustrações de "Klixto" (Calixto Cordeiro), que o acompanham.

Palavras-chave: Gonzaga Duque; prosa; poético.

Abstract: The essay intends to analyze the publication, in Kosmos review (1907), of "Death of Clown", by Gonzaga Duque. There are at least two other versions in books published in 1914 and 1996. The choice of this specific publication stems from aspects considered decisive for some of the senses that can be discussed in the text. Easily assimilated to a metapoetic interpretation that calls into question art as experimentation, "Death of the clown" seems to demonstrate, also, a certain interweaving between what concerns prosaic forms and what concerns poetic forms, in that specific historical moment. It would be possible to associate this case and more recently proposed theoretical questions that would lead to the discussion of the possibility of some transit between two ideals of writing (a "high" ideal and a "low" ideal). A further question concerns the close observable

${ }^{1}$ Professora da Universidade Federal de São Paulo (Unifesp), Departamento de Letras, Escola de Filosofia, Letras e Ciências Humanas, Campus Guarulhos, e no Programa de Pós-Graduação em Letras: <francinericieri@gmail.com>. 
relationship, in Kosmos's version, between the text itself and some ilustrations by "Klixto" (Calixto Cordeiro).

Keywords: Gonzaga Duque; Prosaic Forms; Poetic Forms.

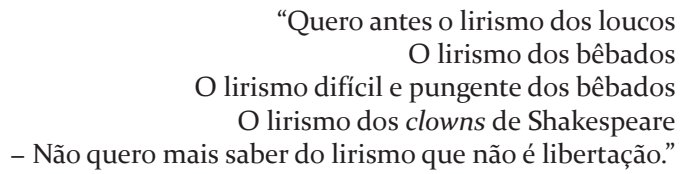

(Manuel Bandeira)

"Por que então a poesia seria a excelência da coisa feita? Porque nada pode ser mais acabado que o acesso ao sentido.

Se ele é, ele é inteiro, de uma exatidão absoluta; ou então ele não é (nem mesmo aproximadamente).

Quando é, ele é perfeito, mais que perfeito.

Quando o acesso tem lugar, sabe-se que ele sempre esteve ali e que, da mesma forma, sempre retornará [...]

O poema obtém o acesso de uma antiguidade imemorial, que nada deve à reminiscência de uma idealidade, mas que é a exata existência atual do infinito, seu retorno eterno. A coisa feita é finita. Sua finição é a perfeita atualidade do infinito." (Jean-Luc Nancy, "Fazer, a poesia")

\section{INCURSÕES TEÓRICAS}

Em uma coletânea em que se coloca em questão o problema teórico do sujeito lírico (RABATÉ, 1996), Jean-Pierre Moussaron escolhe os Petits poèmes en prose, de Charles Baudelaire, como objeto para a preparação de um ensaio em que procura pensar não apenas uma progressiva rarefação teórica do conceito implicado, mas também, ou principalmente, outras rarefações paralelas. Abre sua exposição, nesse sentido, referindo-se a "diversos efeitos de um movimento que parece levar esse grande livro último em direção a um estado bem pouco poético da linguagem", como se o autor nele tivesse sido provocado a "desfazer a matéria lírica de suas obras anteriores" (MOUSSARON, 1996, p. 101). ${ }^{2}$

Percorrendo o livro de Baudelaire, descreve aspectos do que seria um movimento rumo à ruína do poético. O primeiro elemento apontado como concorrente para tal ruína seria a colocação em cena de um tipo de "flâneur", em franco contato com elementos circunstanciais da vida

2 "[...] divers effets d'un mouvement qui semble emporter ce grand texte ultime vers un état bien peu poétique du langage"; "entraîné à défaire la matière lyrique de son oeuvre antérieure".

Remate de Males, Campinas-SP, v.40, n.2, pp. 723-75o, jul./dez. 2020 - 724 
urbana. ${ }^{3} \mathrm{O}$ caráter diversificado da coletânea, em que Moussaron discerne certo pendor para um texto mais prosaico, levaria à discordância de imagens, desnivelamentos de registros e rupturas de tom. Resultaria um efeito múltiplo de desarmonia, frequentemente orquestrado pela ironia, pelo humour noir e pelo sarcasmo agressivo, por vezes com contaminação por um sadismo latente ou manifesto. Mais profundamente, haveria na coletânea muito poucas qualidades e experiências propriamente sublimes, tal como Baudelaire (em texto de 1861 consagrado a Banville) teria descrito os elementos constitutivos, a seus olhos, do lirismo poético. Moussaron pondera, ainda, sobre o que seria um efeito da "perda da auréola" que, nos Petits poèmes en prose, derivaria, ainda, do lugar conferido aos párias, segundo uma "estética do choque".

A imagem da perda da auréola é proposta também em ensaio de Eduardo Veras (2017a) ${ }^{4}$ como elucidativa do papel desempenhado por esse livro de Baudelaire em um movimento específico, aqui em discussão. Veras recorre ao poema em prosa "A perda da auréola" para aludir à travessia de um enlameado bulevar parisiense pelo poeta, que se confronta com a perda do elemento que lhe confere distinção, sua "insígnia divina”. Para o ensaísta, nos Petits poèmes en prose, a tematização da "descida" ou da "queda" do poeta para o mundo dos homens comuns (presente em poemas anteriores) passaria, com a tematização da cidade moderna, a se horizontalizar, convertendo-se em "travessia" do caos urbano, do mundo dos homens comuns. A abordagem do que seria a obsolescência do lugar de distinção social assinalado simbolicamente pela auréola é entendida, ainda por Veras, como uma "dramatização poética da renovação da poesia lírica" (VERAS, 2017a, p. 96), em que é posta em jogo sua dimensão institucional. Sem interpretar esse processo como indiciador de uma recusa, por parte de Baudelaire, da superioridade do poeta em relação aos demais, o crítico acentua, contudo, a presença da cidade como determinante nesse projeto de escrita, com decorrências para o processo de produção e circulação dos textos que viriam a compor os Petits poèmes en prose:

\footnotetext{
${ }^{3}$ Moussaron fundamenta seu raciocínio em Walter Benjamin, o que se pode observar já na escolha de termos como "flâneur" ou "estética do choque". Remeto, ainda, ao ensaio de Benjamin (1984) sobre a origem do drama barroco alemão, que permitiria discutir o conceito de "ruína", presente já no título escolhido pelo crítico francês: "Vers la ruine du poétique”.

${ }^{4}$ Para uma consideração mais abrangente a respeito da "perda da auréola", a propósito de sua configuração nos Pequenos poemas em prosa, remeto a ensaio de Eduardo Veras, de 2017: "A poesia incógnita: elementos para um estudo da poética do Spleen de Paris".
} 
A descida do poeta à cidade pressupõe o reconhecimento do caráter caótico da realidade urbana. Mais uma vez, o poeta se destacará como alguém que prefere dar conta criticamente da realidade a optar pela evasão - não raro hipócrita - de uma visão idealizada da modernidade ou de uma rejeição radical do presente histórico. A horizontalização da experiência poética em Baudelaire se realiza num contato de corpo a corpo com a cidade moderna e seus personagens. Incógnito, livre do peso de toda dignidade poética e encurtada a distância que sua insígnia divina lhe impunha em relação aos homens, o poeta percorre livremente as ruas de Paris, cujos personagens e anedotas aparecem, ao longo dos poemas, como um verdadeiro desafio à inteligência poética. Tentarei mostrar, neste artigo, que a condição do poeta "incógnito", disfarçado de pessoa comum, é um elemento central da poética da prosa baudelairiana, gênero que, em diversos aspectos, também parece recusar as aparências poéticas para se apresentar, sobretudo se consideramos sua relação com o suporte dos jornais, como um gênero perecível e despretensioso. Por trás desse disfarce, veremos que a poesia, ao se apresentar como encenação irônica da fraternidade e da banalidade, termina por se afirmar, paradoxalmente, em sua singularidade em face de seu próprio público e dos outros tipos de discurso dos quais simula uma aproximação (VERAS, 2017a, pp. 97-98).

Seria, talvez, o caso de destacar que a possível opção pela abordagem crítica da realidade (hipótese de Veras) depende da contaminação pelo caráter caótico da cidade, que transita para o projeto poético em preparação, nesse sentido impossibilitado de ser considerado em termos de pureza, isolamento ou afastamento. Não se trata apenas de pensar o poeta (figura internalizada aos textos) que deambula em meio ao caos urbano, mas de pensar um projeto poético em circulação no cerne do caos rebaixado da vida nas grandes cidades. A contaminação implicada no recurso ao suporte jornalístico, assim, reverbera naquilo que o poema em prosa adota como temática e no modo como ele se formaliza, em equação metapoética. Não parece desconectado desse quadro o fato de que paradoxalmente uma singularidade se afirme (a da escrita, a de quem escreve): misturar-se ao caos produzindo-se em arranjos híbridos parece ser condição para que uma tal escrita resista ao genérico, ao que se padroniza e normatiza, e se confronte com a necessidade de respostas que mirem o singular, ainda que tensionando a afirmação de sua possibilidade.

Assim, o que Moussaron delimitou pelo recurso ao conceito benjaminiano de ruína, Veras elabora em termos da proposição de uma poética que depende da produção de uma imagem do poeta/do poema como figuras incógnitas desfilando de modo ambivalente no cenário urbano em confusão. Combinados, tais elementos poderiam contribuir para o propósito de delimitar algumas das questões que os Petits poèmes en prose continuariam a propor à crítica e à historiografia literária, talvez 
à historiografia que pretenda problematizar o tipo de movimento que Moussaron buscou descrever valendo-se da expressão "vers la ruine du poétique". Talvez, por fim, proponham a crítica ao pensamento que pretenda analisar por meio de quais mecanismos historiadores e críticos literários formularam as questões que formularam a respeito desse livro, além dos desdobramentos teóricos que ele suscita. Enfim, contribuiriam, na segunda parte deste ensaio, para pensar fenômenos em alguma medida análogos, discerníveis entre poetas/prosadores ou poetas em prosa, como Cruz e Sousa, Pedro Kilkerry ou Gonzaga Duque, com ênfase em um trabalho deste último.

Como esse Baudelaire tensionaria elementos como a narratividade, a comunicação ea relação com o leitor, a dicção realista, a circulação impressa por meio de jornais, além da relação com o mundo contemporâneo ao ato da escrita, o movimento referido também faz pensar no movimento teórico que descreve a passagem do poema à prosa. Para Moussaron (1996), no caso do livro de Baudelaire em discussão, haveria uma relação significativa entre a apreensão do circunstancial da vida nas grandes cidades e algo como um tipo de embriaguez ou momentos de iluminação veiculados em uma prosa fluida, dúctil, ritmada de modo sutil e, eventualmente, musical (dotada de anáforas, ritmos ternários, assonâncias e aliterações, ecos), em alguns momentos densamente entretecida de imagens desenvolvidas por analogia (indicações assinaladas nas primeiras páginas do ensaio do crítico francês). Em contraponto, Veras enfatiza, no que seria uma poética da prosa em Baudelaire, a resistência à identificação com as marcas convencionalmente atribuídas ao poético ou ao lirismo, em recusa às "aparências poéticas", recuperando, ainda, o que seria o inacabamento do projeto literário Petits poèmes en prose (dos jornais ao livro, das promessas e esboços à concretização editorial por terceiros).

Sem pretender analisar detidamente o fato de que os cerca de vinte anos que separam os dois textos integram um intervalo mais amplo em que se gesta uma radical mudança na abordagem crítica do livro de Baudelaire em discussão, ${ }^{5}$ parece ser o caso de pontuar a historicidade do que, em um e em outro caso, entende-se por prosa (e, em decorrência, o

\footnotetext{
${ }^{5}$ Remeto, nesse sentido, a outro ensaio de Eduardo Veras, "Bagatelas laboriosas", que se abre exatamente com uma reflexão sobre as transformações da recepção crítica de Baudelaire, ao longo do século XX e chegando até produções mais contemporâneas, assinalando o prestígio mais recentemente adquirido pelo Spleen de Paris, bem como possíveis sentidos atribuíveis às mudanças descritas (VERAS, 2017b, pp. 164-193).
} 
que, em um e em outro caso, entende-se por poesia). O próprio Eduardo Veras, em "A poesia incógnita”, reportou-se ao problema, colocando em pauta a discussão da crise das fronteiras da poesia (abordada por Alfonso Berardinelli, em 2007), bem como certa compreensão da tradição da lírica moderna, em termos do que se tem denominado "poesia pura”. Também Marcos Siscar tem discutido o que seria a adoção de um projeto específico de escrita poética como paradigma geral ou universalmente válido de leitura da tradição poética moderna. Nesse processo, um conceito histórico de poesia (o conceito de "poesia pura") teria produzido também leituras críticas e historiográficas de algum modo aderentes ao objeto descrito:

O universo da "poesia pura" como poesia abstrata e ontológica, de renúncia ao real, que recobriria o largo espectro do "esteticismo" do fim do século XIX, permanece como referência central. Mais do que isso, é associado, pela sugestão contida no título, preferencialmente à categoria de "poesia", enquanto as tendências poéticas mais próximas da vida, fusionais, se aproximariam da categoria da "prosa". Reforça-se, portanto, a tendência a identificar não apenas a tradição poética, mas a própria categoria poesia com a ideia de desrealização, de renúncia à vida, de abdicação à socialização (SISCAR, 2016, p. 151).

Nesse sentido, do conceito de "poesia pura" derivariam avaliações da escrita poética como prática do solipsismo, da recusa à comunicação e à realidade, ao passo que "tendências poéticas mais próximas da vida, fusionais”, estariam mais próximas da categoria prosa. Parece interessante que o texto de Moussaron (1996), analisando a relação entre o poeta-narrador e os miseráveis em Petits poèmes en prose chegue ao que seria uma outra dualidade, traçada pelo próprio Baudelaire em 1857 (Notes nouvelles sur Edgar Poe $)^{6}$ entre poema e prosa, em favor da segunda. O

\footnotetext{
${ }^{6}$ Baudelaire (apud MOUSSARON, 1996, p. 107): "Il est un point par lequel la nouvelle a une supériorité, même sur le poème. Le rythme est nécessaire au développement de l'idée de beauté, qui est le but le plus grand et le plus nobre du poème. Or, les artifices du rythme sont un obstacle unsurmontable à ce developpement minutieux de pensées et de expressions qui a pour objet la verité. Car la verité peut être souvent le but de la nouvelle, et le raisonnement, le meilleur outil pour la construction de une nouvelle parfait. C'est pourquoi ce genre de composition qui n'est pas situe à une aussi grande élévation que la poésie pure, peut fornir des produts plus varies et plus facilement appréciables pour le commun des lecteurs. De plus, l'auteur d'une nouvelle a à sa disposition une multitude de tons, de nuances de langage, le ton raisonneur, le sarcastique, l'humoristique, que repudie la poèsie, et qui sont comme des dissonances, des outrages à l'idée de Beauté pure" [Há um ponto no qual o conto é superior até mesmo ao poema. O ritmo é necessário ao desenvolvimento da ideia de beleza, que é o maior e mais nobre objetivo do poema. Ora, os artifícios do ritmo são um obstáculo insuperável ao desenvolvimento minucioso de pensamentos e expressões que tenham por objetivo a verdade. Pois a verdade pode
} 
trecho selecionado pelo ensaísta acentua, no texto indicado, a valorização da prosa pelo escritor, em detrimento do poema, mas Moussaron encerra o parágrafo assinalando que a inclinação para a "Verdade" prevaleceria no livro em questão sobre o cuidado com o "Belo", o que redundaria em riscos de "ultrajes" à "poesia pura". A seção seguinte se inicia de modo também muito significativo: "De fato, o alto conteúdo lírico das Flores do mal aparece singularmente diminuído nos Pequenos poemas em prosa" (MOUSSARON, 1996, p. 107). O elemento rítmico escasso aparece como forte indício desse decréscimo, bem como a notação de se encontrarem bem poucas qualidades e experiências propriamente sublimes. Em outro trecho: "Mas, além dessa destituição do lirismo - de sua origem subjetiva, seu objetivo transcendente, sua estética sublime e seu ritmo específico -, é a qualidade poética da própria coleção que parece ser muito reduzida" (p. 107). ${ }^{7} \mathrm{Ou}$, ainda: "De fato, o alto conteúdo lírico das Flores do mal aparece singularmente diminuído nos Pequenos poemas em prosa" (p. 107)..$^{8}$

O modo historicamente situável como Moussaron descreve a passagem em que se constitui o livro de Baudelaire em discussão foi posteriormente retomado pelo estabelecimento não de uma admissão do prosaico como "baixo" e do poético como "alto", mas do reconhecimento crítico da existência de dois ideais de escrita, diretamente ligados a cada uma dessas possibilidades. ${ }^{9}$ A propósito desse reconhecimento, Marcos Siscar (2016, p. 164) delimitará algo como a "história das negociações da poesia com a prosa”, entendendo que tal história costuma ser abordada de uma perspectiva que prioriza a questão teórica da emergência do poema em prosa. $\mathrm{O}$ crítico prefere, quanto a isso, pensar que a reflexão

muitas vezes ser a meta do conto, e o raciocínio a melhor ferramenta para a construção de um conto perfeito. Eis a razão pela qual esse gênero de composição, que não é tratado com tanta elevação quanto a poesia pura, pode fornecer produtos mais variados e mais acessíveis ao gosto do leitor comum. Além disso, o contista tem à sua disposição uma enorme quantidade de tons, de nuances de linguagem - o tom reflexivo, o sarcástico, o humorístico, que repudia a poesia - e que são como dissonâncias, ultrajes à ideia de beleza pura (BAUDELAIRE, 2012, p. 17)].

7 "Mais, par-delà cette destitution du lyrisme - de son origine subjective, sa visée transcendante, son esthétique sublime et son rythme spécifique -, c'est la qualité poétique même du recueil qui apparaît fort réduite."

8 "De fait, la haute teneur lyrique des Fleurs du mal apparaît singulièrement diminuée dans le Petits Poèmes em Prose."

${ }_{9}$ Ainda Siscar, retomando um posicionamento de Jean-Marie Gleize, lembra que o crítico francês teria oposto algo como um "ideal baixo da literatura" (discernível no Spleen de Paris), por oposição ao que seria um "ideal alto" (como em As flores do mal).

Remate de Males, Campinas-SP, v.40, n.2, pp. 723-75o, jul./dez. 2020 - 729 
moderna poderia ocorrer em termos de uma relação com a forma que fosse refratária a uma visada normativa e identificada com uma relação com o real dissociada daquela anteriormente associada ao objeto "poesia pura":

De minha parte, creio que a relação entre prosa e poesia não se limita à história do poema em prosa, nem revela seus aspectos mais decisivos por meio dela. Tampouco se acomoda à mera inversão da hierarquia, pela exposição de casos em que a prosa poética promoveria a apropriação da "poesia" em uma tradição de prosa. Parece mais consistente retomar a resposta de Agamben à questão da prosa como momento exemplar de uma das vertentes da reflexão contemporânea, que passa a considerar a questão por um prisma filosófico. Antes de Agamben, Michel Deguy, por exemplo em Donnant (de 1981), evoca a "hesitação prolongada entre o poema e a prosa", adaptando a hesitação valeriana entre som e sentido ao contexto de uma discussão mais ampla sobre o lugar prosaico da poesia. Agamben, por sua vez, evita pensar em termos de distinção e de hierarquia de gêneros. Sua abordagem dá destaque ao hibridismo que, nas últimas décadas, tem ocupado um lugar importante na reflexão sobre a literatura e sobre a cultura, associando-a diretamente a questões que são ao mesmo tempo de filosofia, de política e de antropologia, como é o caso da noção de comunidade. Em termos mais próximos da discussão recente sobre a poesia, essa "mestiçagem da poesia com os outros gêneros", na expressão de Jean-Claude Pinson (apud GUILLAUME [...]), faz parte do horizonte de nossa época (SISCAR, 2016, p. 163).

Ainda que o texto de Siscar se reporte ao momento teórico e poético contemporâneo, ele não deixa de ser importante aqui, pois entre os propósitos deste ensaio está a exploração da hipótese segundo a qual alguns textos em prosa escritos no final do século XIX, no Brasil, por intelectuais que são, também, poetas parecem permitir uma reflexão que eventualmente pode ser enriquecida pelo pensamento do hibridismo ou da mestiçagem, bem como das complexas negociações não apenas entre o que pudesse ser da ordem do prosaico e o que pudesse ser da ordem do poético, mas também do trânsito entre "ideal alto" e "ideal baixo" de escrita, do trânsito entre escrita encarcerada e ensimesmada e projetos de deambulação pela grande cidade, além de questões derivadas como a problematização do suporte (o que também levaria a aspectos como inacabamento, comunicabilidade, referencialidade ou sua ausência), bem como de eventuais relações entre o texto escrito e outras linguagens que o acompanhem. Para examinar mais detidamente alguns aspectos desse complexo cruzamento de problemas, parece oportuno referir alguns textos escritos em prosa em que se formulam imagens da escrita, imagens 
do poema, imagens do poeta, imagens da criação artística. E que o fazem tensionando alguns ou vários dos deslizamentos enunciados.

\section{UMA PUBLICAÇÃO EM REVISTA}

Em 1907, no mês de janeiro, a revista Kosmos estampou, quase nas páginas finais daquela edição, um texto assinado por Gonzaga Duque (1863/1911), intitulado "Morte do palhaço". Trata-se de texto curto, que só recebeu edição em livro em $1914^{10}$ (três anos, portanto, após a morte do autor). O leitor da Kosmos (que teve 64 números, entre 1904 e 1909), em 1907 não era advertido por qualquer paratexto quanto a classificações de gênero, mas certamente identificaria naquelas páginas as marcas textuais convencionais da prosa. Em um número em que se encontra também pelo menos um texto denominado "Crônica", ou outros escritos curtos sem designação genérica (como o de Duque), além de escritos de teor científico, "Morte do palhaço" se faz acompanhar por ilustrações assinadas por Calixto Cordeiro (ou "Klixto"). É certo que sua dicção o distingue, de saída, da crônica que, na segunda página do periódico, abre-se comentando que "A propósito do falecimento do visconde de Cabo-Frio, muito se falou, durante o mês, de velhos e velhice, de macróbios e longevidade" (O.B., 1907, [s.p.]). Mas, a que distância estariam as duas contribuições mencionadas?

A propósito de "Morte do palhaço", o primeiro movimento de leitura parece ser despertado exatamente por uma ilustração que, em sua página inicial, ocupa cerca de um quarto do espaço visual e representa uma figura masculina apoiada na letra "e", inicial maiúscula da primeira palavra textualizada ("Esguio"). O homem encontra-se à esquerda do título (que contém o substantivo "palhaço"), no espaço superior da mancha gráfica, e - a despeito de um pequeno chapéu triangular adornado por duas bolas em tom mais escuro e deposto no solo à esquerda de seus pés e talvez pelos botões do colete, que poderiam ser afins aos detalhes do chapéu - em nada lembra um palhaço (não estando, de saída, sequer maquiado) - embora possa indiciar, de certo modo, relações com tal tipo pela contiguidade com o título.

10 "Morte do palhaço" integra o livro Horto de mágoas, que teve sua segunda edição em 1996, com estudo introdutório de Vera Lins e estabelecimento de texto de Júlio Castagnon Guimarães.

Remate de Males, Campinas-SP, v.40, n.2, pp. 723-75o, jul./dez. 2020 - 731 

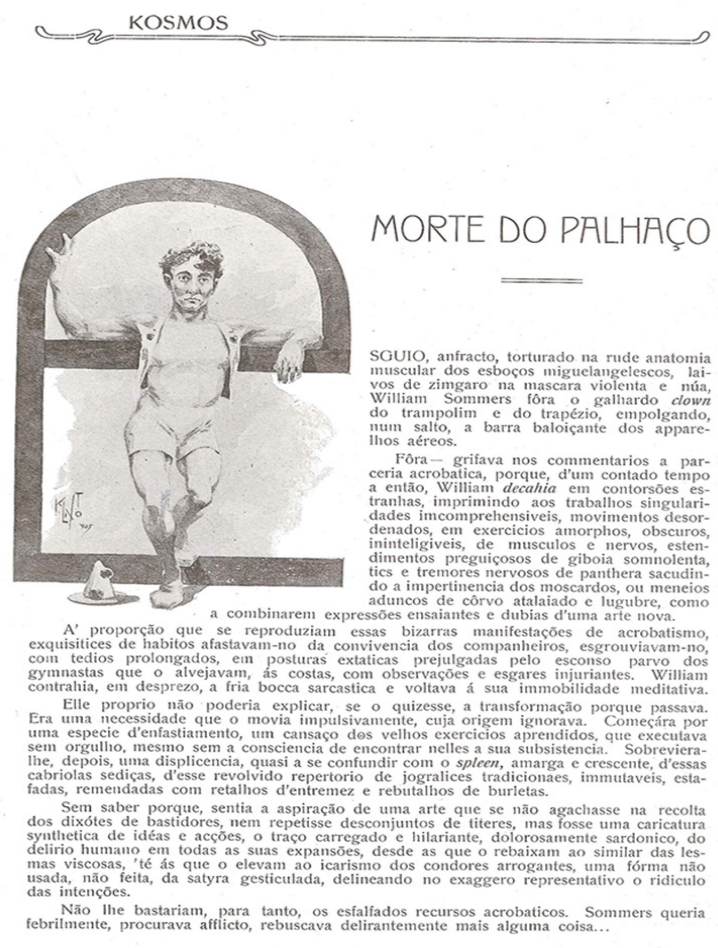

Figura 1 - Página inicial de "Morte do palhaço" (GONZAGA DUQUE, 1907).

Fonte: Kosmos (1907, [s.p.]), reprodução da autora.

Ele veste um calção curto, que cobre talvez um terço de suas coxas musculosas, e um diminuto colete (do qual se podem ver, aliás, apenas duas estreitas tiras dispostas ao longo do torso), em que se vislumbram os referidos botões e que deixam, portanto, à mostra o tronco bem torneado, bem como os braços inteiros. Braços, de resto, totalmente desproporcionais em relação ao conjunto da figura humana, desproporcional, também, em vários de seus outros elementos. A sensação é que os braços, cujas partes superiores repousam apoiadas na linha medial que fecha a cavidade superior do "e", poderiam, se esticados, atingir a metade inferior das pernas, abaixo dos joelhos talvez. Compõe a figura o fato de o braço situado à esquerda de quem olha apoiar-se no suporte superior interno do "e" (com movimento de tração "segurando" esse suporte), enquanto o outro pende, dedos para baixo, na extremidade lateral oposta. O primeiro "agarra" a parede da letra, em paralelo ao chapéu disposto no chão; o 
segundo abandona-se, com alguma displicência, buscando o vão interno à direita.

A concha superior do "e" emoldura, a partir dos braços, um rosto contraído e taciturno, com cabelos em desalinho e um olhar que tem sombras de amargura ou inquietação. As pernas, por sua vez, estão parcialmente dobradas e, como os braços, parecem excessivamente longas para um homem que passa a impressão geral de ser muito baixo, o que acentua a sugestão de um tronco atarracado e muito curto, ainda que musculoso como o conjunto. A postura, por fim, denota certo desequilíbrio: como a mão que segura a letra, toda esta metade do corpo encontra-se mais tensionada, levemente à frente, o que parece sugerir que a perna atrasada (paralela à mão caída), em especial pelas dimensões do calção, seja levemente mais fina. Este pé recuado se apoia na base do "e" (em seu piso) e a porção inferior de ambas as pernas encontra-se à sombra.

É curioso que uma leve inclinação do tronco para a direita de quem observa parece sugerir que o pé de apoio devesse ser, talvez, o que se encontra atrás, mas o conjunto da postura torna essa hipótese pouco provável, e o homem tampouco parece estar em iminência de cair. Toda a metade direita da figura, com exceção dos cabelos, parece diminuída em contraponto com sua equivalente oposta. A franja, mais volumosa nessa metade, compõe, assim, outro dos desequilíbrios, como o fato de o apoio do braço (neste lado) estar sobre a lateral em vão da letra - possivelmente a menos estável e sem apoio. Tudo faz supor, portanto, que a postura se mantenha sobre a perna à esquerda de quem vê, com auxílio da mão em garra - o que permanece contraditório com a totalidade do efeito visual, considerada a inclinação descrita. Mas o parágrafo de abertura parece vir em auxílio do leitor (ou do observador), assim situando o homenzinho:

Esguio, anfracto, torturado na rude anatomia muscular dos esboços miguelangelescos, laivos de zíngaro na máscara violenta e nua, William Sommers fora o galhardo clown do trampolim e do trapézio, empolgando, num salto, a barra baloiçante dos aparelhos aéreos (GONZAGA DUQUE, 1907, [s.p.]).

Ao contrário das incertezas que se delineiam em uma contemplação mais demorada do desenho, a leitura do primeiro parágrafo parece dissolver a possível tensão discernível na relação entre a imagem e o título. Precisamente porque a imagem construída na escrita vai, já em sua abertura, deslocando palhaço de qualquer representação que possa remeter a conotações de leveza ou puerilidade (ou de ingenuidade e 
fragilidade), associando-o, de saída, a um corpo torturado já desde o traço anatômico ("rude anatomia muscular dos esboços miguelangelescos") e aproximado dos clowns shakespearianos, também pela sonoridade do nome escolhido para o personagem (em eventual remissão ao nome do dramaturgo inglês). Esse ser de palavras é associado, então, desde essas linhas iniciais, a um específico ator circense: o acrobata ("galhardo clown do trampolim e do trapézio"). Seu cenário preferencial, nesse sentido, delineia-se como a "barra baloiçante dos aparelhos aéreos". E, considerada a caricatura que acompanha a página inicial, o parágrafo de abertura não faz supor que o designativo "palhaço" possa remeter à mais banalizada (e positiva) visão dessa figura. Palhaço talvez esteja mais próximo de figuras como o pierrot e o arlequim, ou mesmo o saltimbanco, também já estudado por Jean Starobinski.

Vera Lins, talvez a mais importante estudiosa de Gonzaga Duque, na introdução de seu livro Novos pierrôs, velhos saltimbancos, faz exatamente uma síntese da pertinência de personagens mais ou menos afins para uma compreensão que remete à problematização da posição do artista no mundo moderno. Ela lembra, por exemplo, que o pierrô, pinçado na tradição da Commedia dell'arte, configuraria um artista perseguido pela má sorte, "voltado aos acidentes e às quedas mais humilhantes" (LINS, 2009, p. 25). Pierrôs e saltimbancos, assim como o específico palhaço em discussão neste ensaio, contribuiriam para a construção de uma tensa relação entre a criação artística e seus possíveis interlocutores, naquele contexto de finais do século XIX:

Segundo Starobinski, ${ }^{11}$ a figura do saltimbanco, com a qual se identifica o poeta moderno, é contraditória, marca tanto a dependência da imaginação e a subversão da seriedade burguesa quanto o isolamento em que fica o artista face a esse burguês que pede de sua arte apenas o efeito agradável.

Nos saltimbancos de Rilke e Baudelaire e no pierrot de Gonzaga Duque, há esse olhar que vê ao contrário, na trajetória da modernidade, configurando um pensamento que busca a revelação da verdade pelo avesso, pelo negativo, no inverso da ordem das coisas. Como visão mais ampla penetrante, nela, o divino e o diabólico não se distinguem. Aqui, buscam-se ler os escritos sobre arte de Gonzaga Duque, unindo a noção de crítica a uma consciência trágica, ciente dos limites de uma racionalidade que propõe fundamentos e certezas. A crítica radical só é possível com uma consciência de que o mundo não é o que parece. O trágico se preocupa com a verdade, por isso questiona a aparência, a representação, a linguagem. Pode imaginar livremente e articular uma perspectiva utópica (LINS, 2009, p. 22).

\footnotetext{
"Starobinski (1970).
} 
Ainda que estejamos no âmbito da escrita ficcional (enquanto Vera Lins se refere à atuação de Gonzaga Duque como crítico), na abertura de "Morte do palhaço", a caricatura ${ }^{12}$ parece decisiva para o estabelecimento de uma representação pelo avesso, pelo negativo. Ocorre que, sem a textualização (contida no título) de uma figura circense que possa ser pensada como indicativa de alguma inocência e lirismo talvez ingênuo (o palhaço), não se pode efetuar a construção (para a qual seria decisiva a incorporação do traço caricatural) de um trânsito por meio do qual se processa a negação sugerida por Starobinski, bem como a incorporação de certa dimensão trágica, perseguida por Vera Lins nos escritos do autor. Para isso, imbricam-se de modo decisivo o imagético e o verbal: e, na ilustração alocada na abertura do texto, estamos diante de um acrobata cravado no solo, reduzido a sua "rude anatomia muscular", com "laivos de zíngaro" e "máscara violenta e nua”, desprovido portanto do voo (acrobático) que o constituiria artista. Não parece gratuito que o corpo de Sommers esteja enlaçado à palavra que deflagra a narração. Fora da ação que o define, caricatura de si mesmo, ele se paralisa.

Ora, o texto se abre precisamente no registro desse "trânsito" - da passagem de uma condição prévia para outra, que estará finalizada ao término da narrativa. O parágrafo de abertura indica que Sommers "fora o galhardo clown do trampolim e do trapézio", e o seguinte acentua outro momento:

Fora - grifava nos comentários a parceria acrobática, porque, dum contado tempo a então, William decaía em contorções estranhas, imprimindo aos trabalhos singularidades incompreensíveis, movimentos desordenados, em exercícios amorfos, obscuros, ininteligíveis, de músculos e nervos, estendimentos preguiçosos de jiboia sonolenta, tics e tremores nervosos de pantera, sacudindo a impertinência dos moscardos, ou meneios aduncos de corvo atalaiado e lúgubre, como a combinarem expressões ensaiantes e dúbias de uma arte nova.

À proporção que se reproduziam essas bizarras manifestações de acrobatismo, esquisitices de hábitos afastavam-no na convivência dos companheiros, esgrouviavam-no, com tédios prolongados, em posturas extáticas prejulgadas pelo esconso parvo dos ginastas que o alvejavam, às costas, com observações e esgares injuriantes. William contraía, em desprezo, a fria boca sarcástica e voltava à sua imobilidade meditativa (GONZAGA DUQUE, 1907, [s.p.], grifo nosso).

${ }^{12}$ Dos sentidos dicionarizados do vocábulo, recuperamos dois: "1. Desenho que, pelo traço, pela escolha dos detalhes, acentua ou revela certos aspectos caricatos de pessoa ou fato." E “3. Reprodução deformada de algo." (AURÉLIO, 2004, p. 407). 
No processo descrito, está perdido o prestígio de outra época: “fora o galhardo clown do trampolim e do trapézio". Ao comentário panorâmico com o qual o narrador abre a descrição, sucede-se um parágrafo em que se explicita uma avaliação do que talvez fosse um desencaminhamento, um desequilíbrio, fartamente sinalizado na seleção vocabular, na referência às transformações na prática artística do personagem: "William decaía em contorções estranhas"; "singularidades incompreensíveis, movimentos desordenados, em exercícios amorfos, obscuros, ininteligíveis”; "bizarras manifestações de acrobatismo”. A perspectiva dos parceiros de profissão contribui para o quadro: o afastamento é mútuo e se reforça pelo despeito ou desprezo sugeridos ora nos comentários maledicentes indicados na segunda linha, ora nas observações e esgares injuriantes das linhas finais.

Aparentemente desencontrado de sua prática como acrobata, William buscaria "uma arte nova". Ou, ainda, a busca de uma "nova arte" (indiciada nos movimentos que soarão desordenados, nos exercícios que parecerão ininteligíveis?) parece levar ao desencontro que o aparta de seu público e de seus parceiros de atuação. Outro elemento a reforçar a mudança de condição estaria indicado na associação de seus movimentos aos de criaturas como jiboias sonolentas, panteras nervosas, moscardos impertinentes ou corvos atalaiados e lúgubres. Para aquele que fora o "galhardo clown do trampolim e do trapézio", que empolgava em um salto “a barra baloiçante dos aparelhos aéreos”, são associações rasteiras, lentas, rebaixadas, repulsivas ou assustadoras. Mesmo a pantera (em tremores nervosos) o afasta do traço de precisão, e o homem definha em sua "imobilidade meditativa", tomado por "tédios prolongados" e "posturas extáticas”. Na ambiguidade desse acrobata que não se move, marca-se, de todo modo, a efetividade de um processo de experimentação:

Ele próprio não poderia explicar, se o quisesse, a transformação por que passava. Era uma necessidade que o movia impulsivamente, cuja origem ignorava. Começara por uma espécie de enfastiamento, um cansaço dos velhos exercícios aprendidos, que executava sem orgulho, mesmo sem a consciência de encontrar neles a sua subsistência. Sobreviera-lhe, depois, uma displicência, quase a se confundir com o solene, amarga e crescente, dessas cabriolas cediças, desse revolvido repertório de jogralices tradicionais, imutáveis, estafadas, remendadas com retalhos de entremez e rebotalhos de burletas.

Sem saber por quê, sentia a aspiração de uma arte que se não agachasse na recolta dos dichotes dos bastidores, nem repetisse desconjuntos de títeres, mas fosse uma caricatura sintética de ideias e ações, o traço carregado e hilariante, dolorosamente sardônico, do delírio humano em todas as suas expansões, desde as que rebaixam ao similar das lesmas viscosas, até as que elevam ao 
icarismo dos condores arrogantes, uma forma não usada, não feita, da sátira gesticulada, delimitando no exagero representativo o ridículo das intenções. Mas como conseguir essa coisa abstrata? Onde descobrir essa misteriosa forma inovadora, esse mágico, encantado novo que ele pressentia e por cuja conquista se cansava? (GONZAGA DUQUE, 1907, [s.p.]).

Não se trata mais de obter os meios para a subsistência pela realização de "velhos exercícios aprendidos"; trata-se, antes, de perseguir uma forma ainda não usada, algo que se pode pressentir, perseguir, mas não precisamente delimitar. Definindo-se por certo enfastiamento, certo cansaço, Sommers persegue essa misteriosa forma inovadora, "uma caricatura sintética de ideias e ações, o traço carregado e hilariante, dolorosamente sardônico, do delírio humano em todas as suas expansões". Todas as suas expansões: do rebaixamento similar ao das lesmas viscosas ao icarismo dos condores arrogantes. Sobretudo a recusa ao "exercício aprendido" em favor da "caricatura sintética" de ideias e ações.

O entusiasmo de Gonzaga Duque pela arte da caricatura já está devidamente registrado em um texto datado de 1901 (posteriormente recolhido no volume Contemporâneos, de 1929), alusivo ao trabalho exatamente de Klixto (o ilustrador de "Morte do palhaço"), que adotava a assinatura "Klixto":13

De tanto lhe resultou, também, o traço caricaturista. A sua caricatura é o bizarrismo da linha, ainda que pretendendo o aleijão hilariante da estrutura. Abstraída qualquer intencionalidade, que porventura acuse, ela está inteira na maior ou menor destreza da mão do desenhista, é feita para a visão, tem encanto, a garridice da forma. Nada, porém, ele perdeu com a escolha, porquanto seu desenho, nem sempre satisfazendo justos rigores acadêmicos, se torna de tal modo livre, elegante e expressivo, que lembra, por vezes, os conceituados signatários das mais preciosas revistas de ilustrações e das mais estimadas revistas de estampas. [...] De mais a posição do seu desenho é inconfundível. Ainda que torcendo, recalcando, aleijando a linha para conseguir o grotesco da figura, o lápis obedece a uma irresistível propensão para o que os artistas

\footnotetext{
${ }^{13}$ Assim Mônica F. Braunschweiger Xexéo (1987, p. 7) apresenta o trabalho de Klixto: "Desenhista, caricaturista, pintor e capista, Klixto - como costumava assinar suas obras - retratou com ironia e, em certos momentos, com extrema virulência os acontecimentos sociais e políticos de sua época. [...] Colaborador de O mercúrio, O Malho, Tico-Tico, Fon-Fon, $D$. Quixote, entre outros, participou, também, de revistas e jornalecos destinados ao sexo masculino, para os quais fazia desenhos maliciosos. Destacaríamos O Rio $\mathrm{Nu}, \mathrm{O}$ Riso e A Maçã. Essas publicações circulavam clandestinamente no Rio de Janeiro. Ilustrador de mérito, Calixto Cordeiro atingiu certo requinte formal em alguns desses trabalhos (lembraríamos seus desenhos para 'Morte do palhaço', de Gonzaga Duque, e 'O inferno', de Dante, respectivamente para a revista Kosmos e D. Quixote)".
} 
chamam - o chic - desembaraçado de afetação ou de moleza pelo propósito caricatural (GONZAGA DUQUE, 1907, [s.p.]).

A alusão à figura caricata, abordada em regime de senso comum, pode remeter a uma conotação de desmedida, ao escárnio e à desvalorização grotesca, a uma certa facilidade talvez. Gonzaga Duque, ao contrário, parece depreender do "traço caricaturista" (sem recusar alguns desses elementos) de Calixto Cordeiro algo mais: uma espécie de teoria estética, talvez, que, por um lado, possa se permitir a abstração eventual de rigores acadêmicos e, por outro, chegue (precisamente pelo uso de algo de que se aproxima como liberdade) ao elegante e ao expressivo. Nem afetação, nem moleza, um propósito é perseguido e se trata de um propósito que depende menos de intencionalidade do que de "destreza" do gesto. Em "Morte do palhaço" (que aparece na Kosmos seis anos depois desse elogio a Klixto), talvez não seja demais vislumbrar elementos dessa mesma teoria estética: a "caricatura sintética" buscada por Sommers opõe-se a uma arte que se agache "na recolta dos dichotes dos bastidores", ou que repita "desconjuntos de títeres".

Parece possível pensar a hipótese de um efeito curioso que fosse, talvez, obtido pela observação do arranjo gráfico de "Morte do palhaço" naquela edição da Kosmos. Os trechos anteriormente comentados encontram-se todos na primeira página do texto na publicação (a revista não apresenta numeração de páginas), o que coincide com a necessidade de se observar alguém que seria William Sommers: sem maquiagem, posando em seu arranjo algo instável, torso desnudo, chapéu deposto, frontalmente encarando o leitor com seus olhos de dimensões desiguais, enquanto comprime os lábios em expressão carregada, misturando seu corpo ao suporte em que se converte a letra. A página define precisamente uma busca que se fechará com um último parágrafo, de resto muito breve: "Não lhe bastariam, para tanto, os esfalfados recursos acrobáticos. Sommers queria febrilmente, procurava aflito, rebuscava delirantemente alguma coisa..." (GONZAGA DUQUE, 1907, [s.p.]).

Sommers, nessa primeira página, delineia-se no texto de Gonzaga Duque paralelamente à imagem distorcida de um homem fora do trapézio, que vislumbramos pendurado na letra inicial da palavra "Esguio" e que se oferece ao olhar, "torturado na rude anatomia muscular dos esboços miguelangelescos”. A palavra esboço aparece na segunda linha de uma página que se fecha em reticências, encontrando desdobramento possivelmenteapenas na página seguinte. Nogesto, portanto, de prosseguir 
a leitura, ao virar a página, o primeiro impacto que o observador receberá será o de uma ilustração, ainda de Calixto Cordeiro, que parece reincidir exatamente na representação daquela "busca":

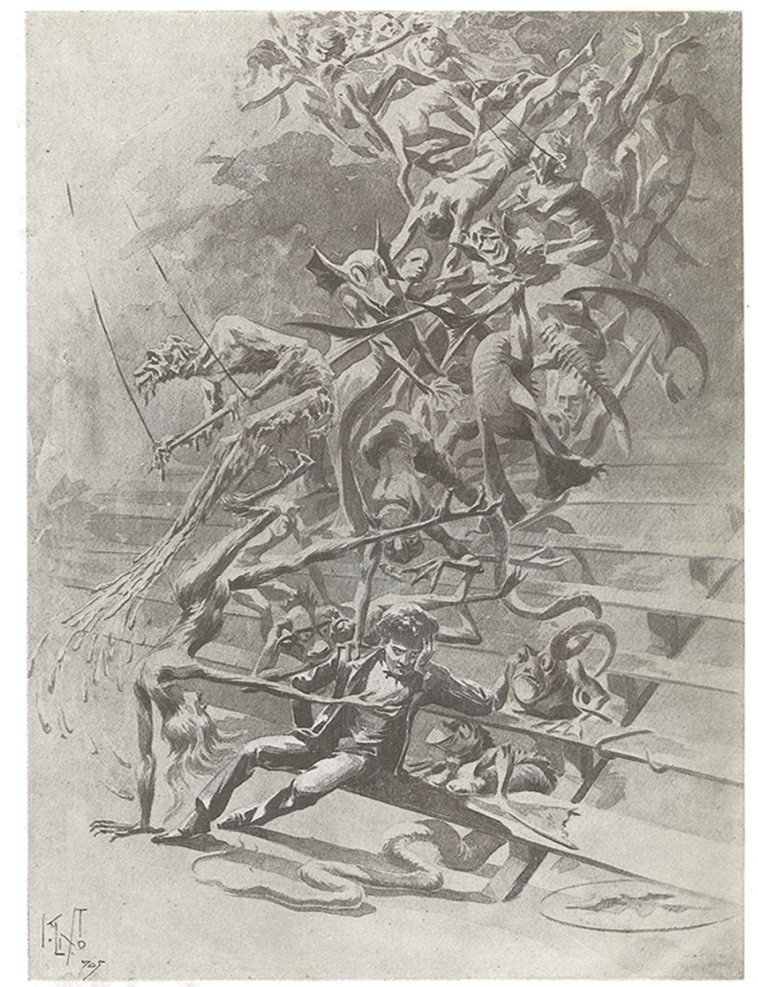

Figura 2 - Ilustração de "Morte do palhaço" (GONZAGA DUQUE, 1907, [s.p.]).

Fonte: Kosmos (1907), reprodução da autora.

A imagem repete a monotonia cromática observada na primeira página, mas insere a narrativa, agora, em sua dimensão mais propriamente trágica. Os movimentos, a transformação, a busca, o caráter febril e delirante - todos os elementos de um processo que é também um percurso torturado são formulados no estatismo do desenho pelo recurso à proliferação sequencial de vultos que parecem recompor, um a um, os quadros de uma ordenação. Observada de alto a baixo, a cena tem início no espaço elevado do trapézio (cujas cordas podem ser discernidas duas vezes) para se fechar nos degraus finais de uma escada que vai progressivamente sendo delineada, do esboço vago (mais ou menos na metade da página) a uma maior precisão (na proximidade do rodapé), e 
em cuja base se encontra a figura humana que corresponderia ao homem representado na página anterior.

Ainda que se possam reconhecer as semelhanças entre as duas versões, a segunda ganha em complexidade e expressividade. As roupas fazem supor a pompa de um momento de atuação, e, do corpo (antes desnudo), podem-se discernir apenas as mãos e o rosto angustiado. À altura dos olhos, uma sombra mais clara parece adensar a dramaticidade de um olhar algo enlouquecido, o que se intensifica ainda mais no gesto de uma das mãos (em amparo à face). Sentada sobre o último dos degraus, a forma humana apresenta-se como a resultante do sequenciamento que se iniciou no alto da página, onde se vislumbra, de início, apenas um conjunto de rostos (talvez cinco) muito diversos entre si, agrupados em torno de uma primeira representação corporal. Todas as imagens são inacabadas, enroscam-se umas às outras e se vão simultaneamente desdobrando em novos arranjos.

Assim, no quarto superior da ilustração, cinco ou seis corpos ladeiam-se, reproduzindo possivelmente a confusão experimental dos movimentos em curso, e o traço dúplice do que seriam duas cordas parece capturar o movimento de uma cabeça em posição difícil de delimitar. Na sequência, em direção à metade do desenho, os torsos enrolam-se ainda mais, um homem muito envelhecido desfaz-se como se derretesse, há algo de burlesco em algumas das faces, outras remetem a animais ou monstruosidades (escamas, asas pontiagudas, costelas, mãos dotadas de barbatanas) e uma das figuras, em franco mergulho, inclui, já na metade inferior do quadro, um traço demoníaco esboçado a partir de chifres, olhos e mãos. Um segundo trapézio, maior e mais nítido, alocado nessa metade superior ainda, mas bem mais próximo de uma eventual linha divisória que partisse a imagem em duas metades, parece mais próximo de quem observa, intensificando o efeito de movimento do conjunto. Os dois trapézios indefinem seu ponto de apoio (que se perde nas névoas superiores do desenho) e transitam da sugestão (do esboço?) à apresentação direta - reforçando a ilusão de deslocamento.

Na metade inferior da página, multiplicam-se ainda os corpos nos movimentos de cerca de três sombras que, contudo, diferem grandemente entre si, ainda que convergindo todas (oscilação de que participa também o demônio descrito) para a figura do homem vestido em traje solene. À direita da figura sentada, pelo menos dois animais, possivelmente um sapo e uma serpente, fecham a curva sinuosa que se delineou desde o alto da imagem. Uma descrição muito precisa certamente apagaria um 
dos efeitos mais interessantes: o embaralhamento, a superposição, a transição. O deslocamento concretiza-se, também, na ambiguidade entre o que possa ser uma escada percorrida em sentido descendente e algo que, por fim, parece definir-se como um fragmento de arquibancada - agora ocupada pelo artista em crise. Assim, o caráter diverso e uno de todos esses corpos nus e em movimento culmina e coincide com o "palhaço" trajado e recomposto, instalado naqueles degraus ou em posição de assistência. Instalado, enfim, na aflição de quem "rebuscava delirantemente mais alguma coisa....

Em sua tese de doutorado, publicada em 1983, Antonio Dimas já refletia sobre a estreita relação entre as ilustrações e os textos no projeto editorial da revista Kosmos. A constatação da forte presença de imagens (caricaturas ou fotografias) levava o crítico a formular a hipótese de que a Kosmos ganhasse em ser compreendida a partir de um contexto "em que a maioria dos escritores disputava, com vaidosa humildade, as calçadas da Rua do Ouvidor e as mesas estratégicas da Pascoal/Colombo para serem vistos", sendo "natural que Kosmos fosse feita mais para os olhos que para o cérebro" (DIMAS, 1983, p. 10). Nesse sentido, "por causa do predomínio marcante da ilustração sobre o texto e por causa da variedade imensa de assuntos tratados", o autor resiste em considerar Kosmos como "revista essencialmente literária” (p. 9), questão que talvez não chegue a ser relevante da perspectiva aqui adotada. O mesmo ensaísta aponta, no entanto, a presença de uma disposição para a mistura, como elemento que então se atualizava em alguns projetos de escrita:

\footnotetext{
Num tempo em que a fúria normativa disciplinava os gêneros, e seus representantes mais ranzinzas mediam o valor do verso pelo critério discutível de riqueza/pobreza rítmica ou o valor do romance pelo apego documental, um carioca atrevido como João do Rio embaralhava propositadamente as cartas, ignorava as regras do bom comportamento jornalístico, embarafustava por locas comprometedoras a fim de proteger do esquecimento os hábitos de tatuagem, a festa do Natal entre os remanescentes da escravaria ou as atitudes viciadas dos candidatos eleitorais (DIMAS, 1983, p. 51).
}

Discernindo movimento semelhante em Gonzaga Duque, Vera Lins (2009, p. 77), por sua vez, tem apontado o que seria, nele, "constante ultrapassagem dos limites dos gêneros". Para ela, ao "entrelaçar ficção e crítica", os textos de Duque "se articulam numa zona de penumbra, em que as fronteiras rígidas entre os gêneros se desfazem” (LINS, 1991, p. 109). Ou ainda: 
Seus contos diluem os limites entre prosa e poesia. Emprestando corporalidade à palavra, ficam entre a pintura e a literatura. As notações visuais criam imagens plásticas em que cores e nuances contribuem ao sentido do texto, como no conto "Idílio roxo" (LINS, 1991, p. 109).

A mesma pesquisadora tem igualmente observado a deferência do escritor para com a ilustração e as artes, em especial a caricatura, no que diz respeito à produção da ironia e do grotesco por meio de processos que lhe parecem de grande relevância, "ainda que torcendo, recalcando, aleijando a linha para conseguir o grotesco da figura” (LINS, 2009, p. 243). No caso de Gonzaga Duque (sem contradição necessária com seus contemporâneos), os olhos parecem precisamente um recurso de que se vale o cérebro, e a ficção, da mesma forma, talvez não se possa definir como "essencialmente literária". ${ }^{14}$ Como ocorre com a revista em que aparece pela primeira vez, a prosa de "Morte do palhaço" implicita um exercício teórico (que faz supor uma crítica das formas artísticas do tempo em que se insere). Como no livro de Baudelaire mencionado anteriormente, o artista encontra-se tematizado e posto em situação problemática e tensa.

Gonzaga Duque (ilustrador de poemas de B. Lopes) parece ter encontrado nas ilustrações de Klixto uma reverberação eloquente, que a publicação de 1907 explicita amplamente. Que o trabalho do desenhista (outro criador) faça de "Morte do palhaço" (tal como publicado na revista) um composto em que se formaliza certa disposição para o hibridismo (para vários hibridismos), parece questão a merecer desenvolvimento mais detido.

\section{MESCLA DE TINTAS}

Decifrando o arquivo de Gonzaga Duque, Vera Lins (1991, p. 109) salienta o trânsito do escritor entre as artes plásticas e a literatura,

\footnotetext{
${ }_{14}$ Também Júlio Castañon Guimarães (2001, pp. 16-17) escreve sobre as relações entre crítica e ficção, em Gonzaga Duque: "A crítica de Gonzaga Duque é uma discussão de concepções, de ideias, atenta à produção contemporânea que está emergindo./ Sua ampla visão cultural cresce na medida em que à sua crítica se acrescenta a produção ficcional. Tanto o romance, Mocidade morta, quanto o livro de contos, Horto de mágoas, são partes integrantes daquela discussão de concepções e ideias. São obras marcadas por evidente esteticismo. Nos contos de Horto de mágoas, além da linguagem esteticizada, destacam-se repetidas referências a elementos artísticos, como quadros de Turner e Corot nas residências dos personagens. Em Mocidade morta, todos os elementos aqui referidos se realçam na medida em que o romance tem como personagens artistas plásticos e críticos. Assim, é possível aproximar o romance e os textos de crítica de Gonzaga Duque, havendo claras relações entre eles".
} 
discernível em seus desenhos, esboços e manuscritos e, em especial, em sua correspondência, que evidenciaria "um percurso de vida e uma busca da linguagem em constante vaivém entre o verbal e o visual, cruzando limites e criando uma tessitura" que uniria "os dois domínios na produção do sentido". O texto, disponível no site da Fundação Casa de Rui Barbosa, transcreve um fragmento manuscrito em que seria possível recuperar algo da incompletude de uma reflexão sobre o processo da escrita:

\begin{abstract}
Residindo os recursos do escritor unicamente nas palavras e tendo ele necessidade de exprimir os mais delicados fenômenos da sensibilidade com os mais sutis pormenores da percepção, é óbvio que.

Aqui o texto para, e além de riscado é interrompido com um grande espaço em branco para continuar mais adiante:

E de que maneira dará ele a sua linguagem esse ronflo de violoncelo, essa crepitação de fogo? Certo que só o conseguiria pelos mesmos artifícios das artes plásticas. Se o colorista que deseja tornar intensa a luz de seu quadro analisa a decomposição química das cores espectrais para certificar-se da complementar, que dará valor aos seus tons, o prosador procura as palavras que, reunidas, propagam pelo valor prosódico a rapidez do vento, o crepitar das chamas, o áspero rodar d'uma carruagem (LINS, 1991, p. 109). ${ }^{15}$
\end{abstract}

O som de um violoncelo e a crepitação do fogo: a demanda de escrita formulada por Gonzaga Duque parece de antemão distanciada de um projeto fundamentado na referencialidade. Antes mesmo de enunciar o desejo de associação com as artes plásticas, o documento já explicita dois elementos que remetem aos sentidos (o som produzido pelo instrumento musical e um híbrido sinestésico que parte também do som sem excluir cor, calor e oscilação visual - tato e visão, portanto, aliados à evidência primeira da audição do que é crepitante). Sentidos, aqui, vale a ênfase, não seriam significados. Sentidos: tato, visão, audição. Ou: calor, imagem, som.

Tentando agora recuperar a lógica proposta no manuscrito, surge a questão: Como a "decomposição química das cores espectrais" poderia ser transposta para o campo da criação literária? Para o prosador que emula o colorista, seria o caso de buscar "as palavras que, reunidas", poderiam propagar pelo "valor prosódico" também estas imagens complexas: a rapidez do vento, o crepitar das chamas, o áspero rodar de uma carruagem. Ora, na gramática tradicional, a prosódia se dedica às características da

${ }_{15}$ Os parágrafos inicial e final são transcrições do documento presente no arquivo em análise. O parágrafo intermediário é comentário da pesquisadora em seu relato sobre o acervo.

Remate de Males, Campinas-SP, v.40, n.2, pp. 723-75o, jul./dez. 2020 - 743 
emissão dos sons da fala, tais como o acento e a entoação. Assim, palavras soando, segundo uma específica entoação, propagariam algo como "a rapidez do vento".

Todo esse processo é fundado no que parece ser, ainda, o propósito do colorista (que se tomou como contraponto do escritor): "tornar intensa a luz de seu quadro". Um escritor, se deseja produzir intensidade, gerar efeitos de intensidade, precisaria, portanto, decompor quimicamente as cores do espectro, imagem que o fragmento atualiza em uma dimensão sonora - em uma enunciação que, ao soar, propaga algo de intenso - que se capta como uma presença, uma epifania, um efeito.

Em "Morte do palhaço", aquele colorista talvez possa ser associado a pelo menos duas instâncias. Inicialmente, temos um narrador que parece almejar propagar pelo valor prosódico do texto algo de quase ininteligível (algo de inatingível) e que diz respeito a certa busca do personagem central - uma busca imprecisa, de algo impreciso, que a escrita não será capaz de objetivar. Paralelamente, um específico artista circense, designado alternativamente como trapezista ou como palhaço, empreende, no curso da história, aquela mesma busca cuja rarefação será dedilhada ao longo das páginas. Sommers, cansado dos velhos exercícios de trapézio, almeja de fato tornar-se o corpo (sonoro) em cuja presença algo de muito intenso (o quê?) se possa atualizar:

E, atento, esmiuçador, tentaculado inteiro por sua ideia, procurava esse segredo, combinando e desfazendo planos, criando e desenhando mentalmente figuras várias, aspectos imprevistos, detalhes impressionantes, aproximando-se do vago debuxo duma harmonia bizarra, logo acentuada nas suas linhas componentes, logo aperfeiçoada nas suas justaposições, mescla de tintas em correspondência reflexa de movimentos rítmicos, o gesto e a cor, a eterna Forma e o eterno Colorido completando-se reciprocamente.

Entrava, então, a avaliar, na mímica expressora duma determinada ideia, qual aflexão que lhe corresponderia, de que maneira conseguiria o acuso caricatural, qual a consonância colorida que deveria externar, por assim dizer: objetivar a intenção. Delirava em torno do seu sonho, seguindo com o olhar doentiamente crepusculado em vagares de outono a marcha trôpega dos rafeiros churros e famintos, a ironia triste dos boêmios envelhecidos; perscrutava a pupila, a atitude, os movimentos dos desamparados, os macilentos das enxovias que riem como os orangos e têm a inquietação farejadora dos roedores, a concentração múrmura dos predestinados para as galés; fundia todo esse penoso estudo em torcicolos e mímicas, em esgares e trejeitos, a lhes descobrir a característica, o flagrante, a nota dominante e certa, a expressão exata sob o desmesurado da sátira, e, esgotado, alquebrado, volvia, impacientemente, a outras investigações, a outras análises, esquecido de tudo quanto não estivesse no disco fascinante dessa obsessão, alheado dos seus deveres, de suas gloríolas de arena, da sua própria existência material (GONZAGA DUQUE, 1907, [s.p.]). 
No primeiro parágrafo transcrito, o caráter perquiridor manifesta-se na escrita por meio de sucessivas enumerações que parecem tentar definir ou, a cada lance, melhor definir o elemento enunciado. Então, associam-se a Sommers, com função adjetiva: atento, esmiuçador e "tentaculado inteiro por sua ideia”. Também a ele se referem as reformulações de ações: combinando e desfazendo planos, criando e desenhando mentalmente figuras várias, aproximando-se do "vago debuxo duma harmonia bizarra”. As figuras mentalmente desenhadas também se multiplicam: figuras várias, aspectos imprevistos, detalhes impressionantes. E o "vago debuxo duma harmonia bizarra” aparece em seguida (à harmonia) "logo acentuada nas suas linhas componentes", "logo aperfeiçoada nas suas justaposições". À mesma harmonia bizarra apõem-se "mescla de tintas em correspondência reflexa de movimentos rítmicos, o gesto e a cor, a eterna Forma e o eterno Colorido completando-se reciprocamente".

A superposição de elementos, sem precisar o que se descreve, parece inflacionar a cena discursiva, produzindo (ou duplicando), no procedimento narrativo, a oscilação febril que caracteriza a busca de Sommers. O trapezista experimenta, e o relato de sua experimentação atualiza-se em uma dicção (do narrador) experimental, oscilante, proliferante. Oprimeiroparágrafosefechasobreumaprofusãodeelementos que poderiam formalizar algum resultado para o processo: movimentos rítmicos, gesto, cor. A expressão "mescla de tintas em correspondência", contudo, parece nuclear, reapresentando-se adiante na duplicidade "a eterna Forma e o eterno Colorido completando-se reciprocamente". São de diversa ordem as misturas: o rítmico, o gestual, o visual. O processo do personagem, por outro lado, é reabsorvido no processo do narrador. E o processo do literato, como discutido anteriormente, reabsorvido no trabalho do ilustrador.

Nesse sentido, no segundo parágrafo transcrito, embaralham-se essas e outras dimensões: a mímica (do trapezista), a caricatura (do artista plástico e do ilustrador), o ritmo reiterativo da escrita (e do narrador), o corpo do palhaço que presentifica as incertezas do projeto. E as diferentes tintas decompostas e em mescla refluem umas por sobre as outras em complexa "correspondência" imagética.

Não parece muito bem sucedido, contudo, o projeto expressivo que pressupõe uma "Ideia" prévia a ser convertida em "forma" (que reenviaria àquela mesma ideia - ou quase). Seria, de fato, possível "objetivar a intenção"? No fragmento de papel depositado no arquivo do escritor, 
tratava-se de conferir à linguagem (com o auxílio dos "artifícios das artes plásticas") o ronflo do violoncelo, a crepitação de fogo. Ou ainda: "a rapidez do vento", “o crepitar das chamas", o "áspero rodar d'uma carruagem”. Eles corresponderiam a qual ideia prévia? A qual ideia prévia corresponderiam: "a marcha trôpega dos rafeiros churros e famintos", a "ironia triste dos boêmios envelhecidos"; "a pupila, a atitude, os movimentos dos desamparados", "os macilentos das enxovias que riem como os orangos e têm a inquietação farejadora dos roedores”, "a concentração múrmura dos predestinados para as galés"?

Quando finalmente se encerra, a busca é concluída em uma cena, em uma apresentação. E, se estamos perseguindo, enfim, uma espécie de "teoria estética" atualizada na figura de Sommers e de sua inquietação, seria talvez relevante sublinhar o quanto seu projeto o afasta do mundo cotidiano e de suas demandas. $\mathrm{O}$ trecho anteriormente transcrito encerra-se assinalando a incompatibilidade entre a "obsessão" do artista, seus deveres e as demandas da vida material. O mergulho progressivamente radicalizado na referida obsessão, irrompe, então, a certa altura em "evento":

E nessa noite, de repente, surdiu da farândola grasnenta dos palhaços, num arranco de trampolim - up! - que o levou à altura dos trapézios.

Foi inesperado. Um sussurro de espanto espalhou-se pelo circo. Quando ele galgou a barra do aparelho, sussurrou, retremendo o ar, um som seco e longínquo de asas de agoiro, o cascalhar indescritível de uma matraca de enterro que soa por noite alta, no silêncio de uma estrada, além... Pelo espaço coriscaram chamas vermelhas, num bafo de inferno. Os espectadores atordoaram-se e lá-cima, na oscilação do trapézio, viu-se o monstro acocorado, quedo, outra vez da translucidez plúmbea de aço horrível. Os grandes olhos ardentes brilhavam em órbitas escavacadas a bistre, na lividez de uma ossamenta artificial apenas ria imóvel, ria sem risos, a feia mandíbula descamada.

Agora, tornara-se mais perturbador, porque se lhe notavam os meneios arrepiados e duros dum fantástico, dum funéreo abutre notívago, de cujo pescoço flácido pendia a carcaça fatídica da Morte para a plateia estupefacta. A distância confundia-o com a probabilidade dum pesadelo. Havia pupilas que fitavam com terror; em rostos exangues, bocas descoradas retorciam gritos invocalizados. E Sommers respirou orgulhoso... [...] Súbito, o incêndio lavrou: o palhaço redemoinhou no espaço, como se houvesse agarrado, aniquilado alguma coisa. A queda dum chuveiro de chumbo estalou, surdamente, refrangiu o ar, passou... E a caveira voltou à sua imobilidade lá no alto, escura e fria, a rir sem risos.

Um silêncio pesava (GONZAGA DUQUE, 1907, [s.p.]).

Vamos nos ater a apenas alguns elementos: a busca é duradoura e se estende, constituindo o enredo da narrativa; a cena que encerra o texto é breve e intensa (o que não é incompatível com o fato de que ocupe uma 
dimensão aproximadamente equivalente à metade da extensão textual); o momento climático irrompe sem previsibilidade possível, uma vez que o processo que levou a esse ponto poderia se estender indefinidamente; a intensidade do efeito depende da irredutibilidade ética ou moral, podendo os conflitos ou turvações éticos adensarem os efeitos ("Pelo espaço coriscaram chamas vermelhas, num bafo de inferno"); ${ }^{16}$ a intensidade do efeito depende, ainda, de algum tipo de afastamento da banalidade do mundo histórico e de suas experiências normalizadas; um momento climático só pode ser efêmero; a efemeridade implica o desvanecimento do evento tão logo ocorra sua finalização. Os parágrafos finais flagrarão, no exato momento de sua mais perfeita atuação, a explosão do corpo do artista contra uma parede. ${ }^{17}$

As duas ilustrações de Klixto sobre as quais não nos estenderemos aqui parecem flagrar exatamente a componente (moralmente?) paradoxal discernível na performance que antecede a morte de William Sommers. A primeira delas representa o trapezista em pleno ato, com seu esgar cadavérico, demoníaco. Cercado de asas gigantescas que podem ou não ser angelicais e das quais se alongam braços portando objetos que podem ser lâmpadas, ele é, contudo, o centro da cena. Como no texto, aparece centrado em seu próprio orgulho, em seu momento de autossuficiência. A última ilustração faz dividirem o espaço o corpo do trapezista em desequilíbrio e desproporção e uma imagem que remeteria ao anjo da morte. Nesse caso, não se identificam no homem as componentes que, na página anterior, a ele conferiam maior ambiguidade. Agora, representa-se o momento da morte - e os traços anatômicos e o gestual perfeccionado (e distorcido em acrobacias) sobressaem. ${ }^{18}$

\footnotetext{
${ }^{16}$ Caberia uma observação indicando, por fim, que a edição em livro de 1996 reproduz apenas duas das ilustrações de Klixto (aquela que comentamos e a última, com o anjo da morte). Como a edição de Kosmos disponível no site da Biblioteca Nacional, por razões desconhecidas, omite a imagem em que o trapezista aparece em plena ação, o leitor que não disponha da edição original da revista poderá consultá-la em bibliotecas ou na presente edição.

${ }^{17}$ Transcrevo: "Nada mais se viu. Então, irrompeu do povo um urra de ovação, sob o barulho das palmas. Mas um baque seco repercutiu no extremo da galeria. Sommers perdeu no voo a barra de um trapézio, atravessou o vácuo, foi arrebentar o crânio numa arquitrave do teto" (GONZAGA DUQUE, 2007, [s.p.]).

${ }^{18}$ Caberia uma nota indicando, por fim, que a edição em livro de 1996 reproduz apenas duas das ilustrações de Klixto (aquela que comentamos e a última, com o anjo da morte). Como a edição de Kosmos disponível no site da Biblioteca Nacional, por razões desconhecidas, omite a imagem em que o trapezista aparece em plena ação, o leitor que não disponha da edição original da revista poderá consultá-la em bibliotecas ou na presente edição.
} 
A experiência estética perfeita se segue, necessariamente, de morte. Talvez seja o caso de recuperar o conceito de "epifania", tal como dele se utiliza Hans Ulrich Gumbrecht, em Produção de presença. O que o sentido não consegue transmitir:

\begin{abstract}
Agora irei concentrar-me, para o sexto passo de meu argumento, no modo específico em que a oscilação entre efeitos de presença e efeitos de sentido se apresenta diante de nós nas situações de experiência estética. A noção que quero usar e desenvolver nesse contexto é epifania. Com "epifania" não quero dizer, de novo, simultaneidade, tensão, oscilação entre sentido e presença; quero dizer, sobretudo, a sensação, citada e teorizada por Jean-Luc Nancy, de que não conseguimos agarrar os efeitos de presença, de que eles - e, com eles, a simultaneidade da presença e do sentido - são efêmeros. De modo mais preciso: sob o título "epifania" pretendo comentar três características que moldam a maneira como se apresenta diante de nós a tensão entre presença e sentido: pretendo comentar a impressão de que a tensão entre presença e sentido, quando ocorre, surge do nada; a emergência dessa tensão como tendo uma articulação espacial; a possibilidade de descrever sua temporalidade como um "evento" (GUMBRECHT, 2010, pp. 140-141).
\end{abstract}

Epifânicos: o som de um violoncelo, a crepitação do fogo, a morte de um palhaço. Uma morte que tenha dependido, para ali se atualizar, da concorrência de um específico modo de se configurar. Mais do que apenas de palavras, do recurso a uma certa prosódia e a suas hesitações, da admissão de um ilustrador e de suas intervenções, da desconfiança das categorizações e definições. Que esse modo esteja em franca tensão com as imagens do poético e da poesia naquele final do XIX (e na leitura que se faz do período), talvez seja tarefa que não se possa demonstrar aqui. Invertendo, contudo, o sentido vetorial (axiológico) implicado nas reticências quanto àquilo que de "essencialmente literário" se possa publicar em uma revista como Kosmos (do alto ao baixo, do baixo ao alto), talvez se possa esboçar uma última mescla de tintas, em que o poético se ofereça também à reflexão. Com ou sem auréolas. Algo que se faz.

\title{
REFERÊNCIAS
}

BANDEIRA, Manuel. Poética. In: Estrela da vida inteira. Rio de Janeiro: José Olympio, 1988, p. 98.

BAUDELAIRE, Charles. Outras anotações sobre Edgar Poe. In: POE, Edgar Allan. Contos de imaginação e de mistério. Trad. Cássio de Arantes Leite. São Paulo: Tordesilhas, 2012. 
BENJAMIN, Walter. Origem do drama barroco alemão. Trad., apres. e notas Sérgio Paulo Rouanet. São Paulo: Brasiliense, 1984.

CORDEIRO, Calixto. Catálogo de Exposição. Museu Nacional de Belas Artes. Apresentação de Alcídio Mafra de Souza. Depoimento de Antônio Nássara. Textos de Mônica F. Braunschweiger Xexéo e Marcus Tadeu Daniel Ribeiro. Rio de Janeiro: Museu Nacional de Belas Artes, 1987.

DIMAS, Antonio. Tempos eufóricos. (Análise da revista Kosmos: 1904-1909). São Paulo: Ática, 1983.

GONZAGA DUQUE. Morte do palhaço. Kosmos, Rio de Janeiro, Ano IV, n. 1, jan. 1907, [s.p.].

GONZAGA DUQUE. Morte do palhaço. In: Horto de mágoas: contos. 2. ed. Org. Vera Lins e Júlio Castañon Guimarães. Rio de Janeiro: Secretaria Municipal de Cultura, Departamento Geral de Documentação e Informação Cultural, Divisão de Editoração, 1996.

GONZAGA DUQUE. Impressões de um amador. Textos esparsos de crítica (1882-1909). Org. Júlio Castagnon Guimarães e Vera Lins. Belo Horizonte: Editora UFMG, 2001.

GUIMARÃES, Júlio Castañon. Empenho crítico: Gonzaga Duque na imprensa. In: GONZAGA DUQUE. Impressões de um amador. Textos esparsos de crítica (1882-1909). Org. Júlio Castagnon Guimarães e Vera Lins. Belo Horizonte: Editora UFMG, 2001, pp. 11-24.

GUMBRECHT, Hans Ulrich. Epifania / Presentificação / Dêixis: futuros para as Humanidades e as Artes. In: A produção da presença. O que o sentido não consegue transmitir. Rio de Janeiro: Contraponto/Editora PUC Rio, 2010.

HOLANDA, Aurélio Buarque de. Caricatura. In: Novo dicionário Aurélio da língua portuguesa. Curitiba: Positivo, 2004.

LINS, Vera. Linhas cruzadas: decifrando o arquivo de Gonzaga Duque. Fundação Casa de Rui Barbosa [site]. [s.d.]. Disponível em: <http://www.casaruibarbosa. gov.br/dados/DOC/artigos/k-n/FCRB_VeraLins_Linhas_cruzadas_decifrando_ arquivo_GonzagaDuque.pdf>. Acesso em: 17 nov. 2020.

LINS, Vera. A estratégia do franco-atirador. Rio de Janeiro: Tempo Brasileiro, 1991.

LINS, Vera. Novos pierrôs, velhos saltimbancos. Os escritos de Gonzaga Duque e o final do século XIX carioca. 2. ed. Rio de Janeiro: EdUERJ, 2009.

MOUSSARON, Jean-Pierre. Vers la ruine du poétique. In: RABATÉ, Dominique; SERMET, Joëlle de; VADÉ, Yves. Le sujet lyrique en question. Modernités. Bordeaux: Presses Universitaires de Bordeaux, 1996, pp. 101-128. 
NANCY, Jean-Luc. Fazer, a poesia. Alea, Rio de Janeiro, v. 15, n. 2, dez. 2013, pp. 414-422. Disponivel em: <http://www.scielo.br/scielo.php?script=sci_arttext\&pid=S1517-

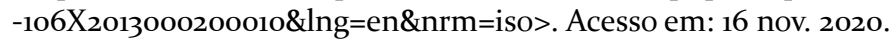

O.B. Crônica. Kosmos, Rio de Janeiro, ano IV, n. 1, jan. 1907, [s.p.].

SISCAR, Marcos. De volta ao fim. O "fim das vanguardas" como questão da poesia contemporânea. Rio de Janeiro: 7 Letras, 2016.

STAROBINSKI, Jean. Portrait de l'artiste en saltimbanque. Paris: Flammarion, 1970.

VERAS, Eduardo. A poesia incógnita: elementos para um estudo da poética do Spleen de Paris. Remate de Males, v. 37, n. 1, 2017a, pp. 93-116.

VERAS, Eduardo. Bagatelas laboriosas. Ambivalências do lugar-comum na poesia em prosa de Baudelaire. Revista Terceira Margem, v. 35, jan.- jun. 2017b, pp. 164-193.

XEXÉO, Mônica F. Braunschweiger. [Apresentação do trabalho de Klixto]. In: CORDEIRO, Calixto. Catálogo de exposição do Museu Nacional de Belas Artes. Rio de Janeiro: Museu Nacional de Belas Artes, 1987, pp. 7-8.

Recebido: $15 / 5 / 2020$

Aceito: 15/7/2020

Publicado: 2/12/2020

Remate de Males, Campinas-SP, v.40, n.2, pp. 723-75o, jul./dez. 2020 - 750 